\title{
PEMANFAATAN RUMPUT GAJAH SEBAGAI SUMBER SILIKA UNTUK SINTESIS ZEOLIT T
}

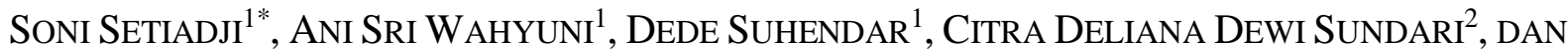 \\ ATTHAR LUQMAN IVANSYAH ${ }^{3}$ \\ ${ }^{1}$ Jurusan Kimia, Fakultas Sains dan Teknologi, UIN Sunan Gunung Djati Bandung, \\ Jl. A. H. Nasution No. 105 Cibiru Kota Bandung
}
${ }^{2}$ Program Studi Pendidikan Kimia, Fakultas Tarbiyah dan Keguruan, UIN Sunan Gunung Djati Bandung, Jl. A. H. Nasution No. 105 Cibiru Kota Bandung
${ }^{3}$ Program Studi Magister Sains Komputasi, Fakultas Matematika dan Ilmu Pengetahuan Alam, Institut Teknologi Bandung
Jl. Ganesha No. 1 Lb. Siliwangi, Coblong, Kota Bandung
*alamat email korespondensi: s.setiadji@uinsgd.ac.id

\begin{abstract}
Informasi Artikel
Riwayat Naskah : Diterima pada 27

November 2017

Diterima setelah direvisi pada 27

Desember 2017

Diterbitkan pada 29

Desember 2017

Kata Kunci:

Rumput gajah; hidrotermal; zeolit $\mathrm{T}$ isolasi silika; membran zeolit.

Keywords: Elephant grass, zeolite T; hydrothermal; silica isolation; zeolite membrane

\section{Abstrak/Abstract}

Zeolit $\mathrm{T}$ merupakan salah satu tipe zeolit yang digunakan sebagai bahan membran untuk pemisahan gas. Penggunaan silika sebagai prekursor untuk mensintesis zeolit perlu dioptimalkan. Dalam studi ini, sumber silika diperoleh dengan memanfaatkan bahan yang alami, yakni dari rumput gajah. Silika diperoleh dengan cara isolasi dari abu rumput gajah menggunakan $\mathrm{NaOH}$. Silika yang diperoleh dari hasil isolasi rumput gajah memiliki persentase sebesar 71,91\%. Zeolit $\mathrm{T}$ di sintesis dengan komposisi molar $1 \mathrm{SiO}_{2}: 0,025 \mathrm{Al}$ : $0,15 \mathrm{Na}_{2} \mathrm{O}: 0,15 \mathrm{~K}_{2} \mathrm{O}: 15 \mathrm{H}_{2} \mathrm{O}:$ dan $0,06 \mathrm{TMAOH}$ dengan proses hidrotermal selama 4 hari, yaitu 2 hari pertama pada temperatur $60^{\circ} \mathrm{C}$, dilanjutkan 2 hari berikutnya pada temperatur $120^{\circ} \mathrm{C}$. Proses inkubasi tersebut mentransformasi silika amorf menjadi kristal zeolit T. Zeolit yang dihasilkan dikarakterisasi dengan difraksi sinar-X (XRD) untuk mengkonfirmasi terbentuknya zeolit T, spektroskopi inframerah (FTIR) untuk mengkonfirmasi jenis ikatan yang terbentuk dan mikroskop pemindai elektron (SEM) untuk melihat morfologi zeolit T.

Zeolite $T$ is a type of zeolite that is used as a membrane material for gas separation. The use of silica as a precursor to synthesize zeolite needs to be optimized. In this study, the source of silica was obtained by utilizing natural materials, that is from elephant grass. Silica is obtained by isolation from the ash of elephant grass using $\mathrm{NaOH}$. Silica obtained from the isolation of elephant grass has a percentage of $71.91 \%$. Zeolite T was synthesized with molar composition $1 \mathrm{SiO}_{2}: 0.025 \mathrm{Al}: 0.15 \mathrm{Na}_{2} \mathrm{O}: 0.15 \mathrm{~K}_{2} \mathrm{O}: 15 \mathrm{H}_{2} \mathrm{O}:$ and $0.06 \mathrm{TMAOH}$ via a hydrothermal process along four days, which divided into the first two days at $60^{\circ} \mathrm{C}$ and directly continued by two days at $120^{\circ} \mathrm{C}$. The incubation process transforms amorphous silica into zeolite T crystals. The resulting zeolite was characterized by X-Ray Diffraction (XRD) to confirm the formation of zeolite T, Infrared Spectroscopy (FTIR) to confirm the type of bond formed and Scanning Electron Microscope (SEM) to see zeolite T morphology.
\end{abstract}

\section{PENDAHULUAN}

Zeolit merupakan kelompok material aluminosilikat yang dihasilkan melalui proses hidrotermal. Penyusun utama yang membangun struktur zeolit adalah $\mathrm{SiO}_{2}$ dan $\mathrm{Al}_{2} \mathrm{O}_{3}$ yang membentuk tetrahedaral yang terikat melalui penggunaan bersama atom oksigen [1]. Zeolit dapat diaplikasikan sebagai katalis, adsorben, membran untuk pemisahan gas, proses ozonisasi karena memiliki stabilitas termal atau hidrotermal yang baik dan juga memiliki kepasitas sebagai penukar ion yang tinggi [2]. Salah satu zeolit yang banyak diaplikasikan sebagai membran untuk pemisahan gas adalah zeolit $\mathrm{T}$ [3]. Zeolit $\mathrm{T}$ merupakan intergrowth dari tipe Erionit dan Offretit yang dapat diaplikasikan sebagai pengubah metanol menjadi $\mathrm{C}_{2}-\mathrm{C}_{5}$ olefin, selektif terhadap retakan n-parafin [4], membran untuk pemisahan campuran gas $\mathrm{CO}_{2} / \mathrm{CH}_{4}$, campuran $\mathrm{CO}_{2} / \mathrm{N}_{2}$ dan campuran organik dengan mekanisme pemisahan molekul [5].

Secara umum, sintesis zeolit dilakukan dengan proses hidrotermal menggunakan prekursor yang mengandung silika, alumina, kation logam alkali atau alkali tanah dan adanya OSDA (Organic Srtucture Directing Agent) atau templat organik [6]. OSDA berperan sebagai pengarah struktur 
kerangka zeolit, sedangkan templat berberan sebagai cetakan terhadap zeolit yang disintesis. Tetrametil amonium hidroksida (TMAOH) merupakan templat organik yang umumnya digunakan untuk sintesis zeolit $\mathrm{T}$ [3]. Pada umumnya, sumber silika untuk sintesis zeolit menggunakan TEOS (Tetra Ethyl Ortho Silicate), LUDOX atau $\mathrm{Na}_{2} \mathrm{SiO}_{3}$. Namun, ketiga sumber silika tersebut memiliki kekurangan, yaitu harganya relatif mahal, sulit didapat serta bahannya yang tidak ramah lingkungan [7].

Pada penelitian ini, akan dilakukan sintesis zeolit T menggunakan sumber silika yang diisolasi dari rumput gajah. Pemanfaatan tesebut karena rumput gajah termasuk jenis rumput liar sehingga mudah didapat. Selain itu, merujuk pada penelitian sebelumnya yang menyebutkan bahwa tumbuhan golongan Graminae merupakan contoh kelompok tanaman yang memiliki kandungan silika. Oleh karena itu, dapat dipastikan bahwa rumput gajah mengandung silika. Silika akan diperoleh dengan cara isolasi dengan menggunakan larutan basa karena silika larut dalam pelarut alkalis/basa [8].

Dalam penelitian yang telah dilaporkan oleh Bohra et al. (2013), zeolit $\mathrm{T}$ berhasil disentesis dengan menggunakan abu sekam padi sebagai sumber silika yang disintesis secara hidrotermal [9]. Akan tetapi, pada penelitian ini zeolit T akan disintesis menggunakan abu rumput gajah sebagai sumber silika.

Pada umumnya, zeolit $\mathrm{T}$ di sintesis dengan memerlukan waktu inkubasi yang cukup lama dan dengan temperatur konstan. Akan tetapi, menjadi kurang efisien karena membutuhkan banyak energi. Seperti salahsatu penelitian yang dilaporkan oleh Yin et al., sintesis zeolit T dilakukan selama 172 jam dengan temperatur $100^{\circ} \mathrm{C}$. Akan tetapi, dalam jurnal tersebut dilaporkan juga zeolit $\mathrm{T}$ berhasil di sintesis dengan beberapa variasi temperatur dan variasi waktu inkubasi [10]. Penelitian ini akan merujuk pada penelitian tersebut, yang mana variasi waktu inkubasi dan temperatur yang di pilih adalah 2 hari pertama pada temperatur $60^{\circ} \mathrm{C}$, dilanjutkan 2 hari berikutnya pada temperatur $120^{\circ} \mathrm{C}$. Waktu dan temperatur tersebut dipilih karena menunjukan hasil yang paling baik dibandingkan variasi waktu dan temperatur lainnya.

Diharapkan hasil penelitian ini dapat berkontribusi untuk memanfaatkan rumput gajah yang ada di Indonesia supaya dapat meningkatkan nilai guna dari rumput gajah baik dari segi pemanfaatan silika, maupun digunakan sebagai sumber silika untuk sintesis zeolit. Selain itu, diharapkan zeolit yang dihasilkan memiliki kinerja yang relatif baik.

\section{EKSPERIMEN}

\section{Material}

Bahan-bahan yang digunakan dalam penelitian ini adalah daun rumput gajah, $\mathrm{NaOH}$ (p.a), $\mathrm{KOH}$ (p.a), logam $\mathrm{Al}$ (p.a), TMAOH 25\%, kertas saring Whatmann, kertas timbang dan akua $\mathrm{dm}$

\section{Instrumentasi}

Instrumen yang digunakan dalam penelitian adalah Scanning Electron Microscope- Energy Dispersive X-Ray (SEM-EDX) JCM-6000, Fourier Transform InfraRed (FT-IR) Carry 600 Agilent Technologies, X-Ray Diffraction (XRD) Philips PW 1835, $\mathrm{CuK} \alpha, \mathrm{k}=1,54060 \AA$, dan $X$-Ray Fluorescence (XRF).

\section{Prosedur}

\section{Preparasi dan Isolasi Silika Rumput Gajah}

Isolasi silika dari rumut gajah mengadopsi metode yang digunakan oleh penelitian sebelumnya [8]. Rumput gajah yang digunakan diperoleh dari lingkungan kampus UIN Sunan Gunung Djati Bnadung. Tahap awal daun rumput gajah dicuci hingga bersih dan dikeringkan dengan oven pada suhu $110^{\circ} \mathrm{C}$. Rumput gajah yang telah dikeringkan kemudian diabukan dengan menggunakan furnace pada temperatur $550^{\circ} \mathrm{C}$ selama 5 jam untuk menghilangkan zat-zat organik. Abu yang diperoleh selanjutnya dilarutan dengan $1 \mathrm{M}$ larutan $\mathrm{NaOH}$ yang disertai pemanasan pada temperatur $150^{\circ} \mathrm{C}$ dan pengadukan selama 1 jam yang dilanjutkan dengan tahap penyaringan. Selanjutnya filtrat yang diperoleh ditambahkan tetes demi tetes $3 \mathrm{M}$ larutan $\mathrm{H}_{2} \mathrm{SO}_{4}$ sampai $\mathrm{pH}$ larutan menjadi 7 kemudian didiamkan selama semalam. Gel yang terbentuk selanjutnya dicuci dengan akua dm panas dan dikeringkan di dalam oven pada temperatur $110^{\circ} \mathrm{C}$ selama 24 jam. Silika yang terbentuk dihaluskan, selanjutnya dianalisis dengan XRD, FT-IR, dan SEM-EDX serta digunakan sebagai sumber silika untuk sintesis zeolit.

\section{Sintesis Zeolit T}

Zeolit $\mathrm{T}$ disintesis dengan mengadopsi metode yang dilakukan oleh penelitian sebelumnya [10]. Zeolit $\mathrm{T}$ disintesis dengan menggunakan prekursor silika rumput gajah, logam $\mathrm{Al}$, padatan $\mathrm{NaOH}$, padatan $\mathrm{KOH}$, templat 
organik TMAOH dan akua DM. Komposisi molar yang digunakan $1 \mathrm{SiO}_{2}: 0,025 \mathrm{Al}: 0,15 \mathrm{Na}_{2} \mathrm{O}: 0,15$ $\mathrm{K}_{2} \mathrm{O}: 15 \mathrm{H}_{2} \mathrm{O}: 0,06$ TMAOH dengan waktu inkubasi 4 hari, 2 hari pertama pada temperatur $60^{\circ} \mathrm{C}$, dilanjutkan 2 hari berikutnya pada temperatur $120^{\circ} \mathrm{C}$.

Tahap awal adalah melarutkan logam Al sejumlah $0,1176 \mathrm{~g}$ dengan larutan $\mathrm{NaOH}$ di dalam botol polipropilen. Larutan tersebut ditambahkan dengan padatan $\mathrm{KOH}$ sejumlah 1,4646 g dan akua DM sejumlah $12 \mathrm{~mL}$ dalam kondisi pengadukan pada temperatur ruang. Selanjutnya ditambahkan larutan TMAOH sejumlah $0,4697 \mathrm{~mL}$ ke dalam botol polipropilen. Setelah semua larutan tercampur ditambahkan silika sejumlah 7,2850 g secara perlahan dalam kondisi pengadukan. Larutan diaduk selama kurang lebih 20 jam sampai menghasilkan gel prekursor. Gel prekursor yang terbentuk dipindahkan ke dalam autoklaf dan diinkubasi dalam oven selama 4 hari, 2 hari pertama pada temperatur $60^{\circ} \mathrm{C}$, dilanjutkan 2 hari berikutnya pada temperatur $120^{\circ} \mathrm{C}$. Setelah autoklaf mencapai temperatur ruang, padatan dipisahkan dari campuran dengan cara disentrifugasi, dicuci dengan akua DM dan dikeringkan pada temperatur $100^{\circ} \mathrm{C}$ selama 12 jam. Untuk menghilangkan templat organik yang digunakan padatan yang diperoleh dikalsinasi pada temperatur $550^{\circ} \mathrm{C}$ selama 7 jam. Zeolit yang terbentuk dianalisis dengan instrumen XRD, FTIR, dan SEM.

\section{Karakterisasi}

Kristalinitas silika dan zeolit ditentukan menggunakan analisis difraksi sinar-X (XRD, Philips PW 1835 X-ray Diffractometer, $\mathrm{CuK} \alpha, \mathrm{k}=$ 1,54060 Å). Struktur zeolit $\mathrm{T}$ (erionit) akan memberikan puncak khas yang tinggi dalam pola difraksi sinar-X pada $2 \theta=7,69^{\circ}, 13,34^{\circ}, 23,65^{\circ}$, $24,90^{\circ}, 26,87^{\circ}, 28,35^{\circ}, 31,46^{\circ}$ dan $33,38^{\circ}$. Untuk ikatan pada zeolit $\mathrm{T}$ dilakukan analisis menggunakan Fourier Transform Infra Red (FTIR, Agilent Carry 600). Morfologi permukaan partikel zeolit mordenit ditentukan menggunakan analisis Scanning Electron Microscopy (JCM6000)

\section{HASIL DAN PEMBAHASAN}

\section{Sintesis Senyawa Kompleks}

Dalam penelitian ini silika diperoleh dengan menggunakan metode isolasi yang bersumber dari daun rumput gajah yang berasal dari UIN Sunan Gunung Djati Bandung. Kandungan silika setiap sumber berbeda-beda yang disebabkan jenis sumber dan letak geografis. Rumput gajah dijadikan sebagai sumber silika karena termasuk jenis rumput liar dengan jumlah yang melimpah sehingga mudah didapat. Selain itu, silika dari rumput gajah memiliki kandungan yang lebih tinggi dibandingkan dengan kandungan senyawa anorganik lainnya yang diperlihatkan dalam Tabel 1.

Tabel 1. Komposisi Zat Anorganik pada Rumput Gajah

\begin{tabular}{lccc}
\hline Komponen & $\begin{array}{c}\text { Kandungan } \\
(\text { massa \%) }\end{array}$ & Senyawa & $\%$ Massa \\
\hline Karbon & 0,78 & $\mathrm{Na}_{2} \mathrm{O}$ & 2,69 \\
Oksigen & 42,41 & $\mathrm{MgO}$ & 0,59 \\
Natrium & 0,22 & $\mathrm{SiO}_{2}$ & 71,91 \\
Magnesium & 0,36 & $\mathrm{~K}_{2} \mathrm{O}$ & 4,31 \\
Silikon & 33,61 & $\mathrm{Tm}_{2} \mathrm{O}_{3}$ & 19,72 \\
$\mathrm{Kalium}_{\mathrm{Tm}_{2} \mathrm{O}_{3}}^{3,58}$ & & \\
\hline
\end{tabular}

Penelitian diawali dengan preparasi sampel dengan mencuci bersih rumput gajah yang dilanjutkan dengan pengeringan di dalam oven untuk menghilangkan pengotor dan kadar air. Selanjutnya rumput diabukan dengan cara kalsinasi pada temperatur $550^{\circ} \mathrm{C}$ selama 5 jam menggunakan furnace.

Kalsinasi dilakukan untuk menghilangakan pengotor organik yang terdapat di dalam sampel. Pengabuan dilakukan pada temperatur di bawah $700^{\circ} \mathrm{C}$ untuk mencegah terjadinya transformasi silika yang berbentuk amorf menjadi kristalin [11]. Karena temperatur dapat mentransformasi silika amorf ke silika kristalin, dengan demikian temperatur harus di jaga agar silika tetap reaktif sehingga dapat digunakan untuk sintesis zeolit.

Faktor lain yang mempengaruhi terbentuknya silika kristalin disebabkan oleh keberadaan senyawa-senyawa pengotor anorganik lainnya seperti $\mathrm{K}$ dan $\mathrm{Na}$ yang dapat menurunkan titik leleh silika sehingga dapat mempercepat perubahan fasa menjadi kristalin [12]. Silika amorf digunakan untuk sintesis zeolit karena mempunyai kereaktifan yang tinggi karena adanya gugus silanol ( $\mathrm{Si}-\mathrm{OH})$ sehingga mudah untuk bereaksi [13].

Proses isolasi dimulai menambahkan larutan $\mathrm{NaOH}$ ke dalam abu. Hal ini dilakukan berdasarkan prinsip bahwa silika larut dalam basa dan mudah mengendap ketika ditambahkan asam. Abu ditambahkan dengan $1 \mathrm{M}$ larutan $\mathrm{NaOH}$ disertai pengadukan dalam kondisi panas untuk mempermudah proses pelarutan $\mathrm{SiO}_{2}$. Penggunaan larutan $\mathrm{NaOH}$ karena silika hanya larut dalam larutan alkali hidroksida [14]. Reaksi antara silika dan larutan $\mathrm{NaOH}$ akan menghasilkan larutan $\mathrm{Na}_{2} \mathrm{SiO}_{3}$ dengan reaksi sebagai berikut : 


$$
\mathrm{SiO}_{2(S)}+2 \mathrm{NaOH} \rightarrow \mathrm{Na}_{2} \mathrm{SiO}_{3(a q)}+\mathrm{H}_{2} \mathrm{O}_{(l)}(1)
$$

Silika dari abu rumput gajah dalam larutan $\mathrm{NaOH}$ menghasilkan larutan natrium silikat yang dipisahkan dengan cara penyaringan. Filtrat yang diperoleh direaksikan dengan larutan $3 \mathrm{M}$ larutan $\mathrm{H}_{2} \mathrm{SO}_{4}$ untuk mengikat $\mathrm{SiO}_{2}$ sehingga dihasilkan $\mathrm{SiO}_{2}$ berbentuk gel berwarna putih. Gel putih terbentuk karena sudah tidak ada lagi pengotor organik seperti selulosa yang mengganggu proses isolasi. Penambahan larutan asam berperan untuk mengikat silika juga dapat menghilangkan pengotor-pengotor anorganik yang terkandung di dalam abu.

$\mathrm{Na}_{2} \mathrm{SiO}_{3}+\mathrm{H}_{2} \mathrm{SO}_{4} \rightarrow \mathrm{SiO}_{2}+\mathrm{Na}_{2} \mathrm{SO}_{4}+\mathrm{H}_{2} \mathrm{O}(2)$

Penambahan larutan $\mathrm{H}_{2} \mathrm{SO}_{4}$ pada proses ini berperan sebagai agen pengendap untuk mengendapkan silika. Larutan asam lain seperti asam klorida dan asam nitrat juga dapat digunakan sebagai agen pengendap. Pengendapan ditandai dengan terbentuknya endapan gel pada larutan. Silika dapat membentuk gel pada $\mathrm{pH}$ di bawah 10 karena kelarutannya rendah pada $\mathrm{pH}$ tersebut, sehingga untuk mendapatkan gel silika dari natrium silikat $\mathrm{pH}$ harus diturunkan. Pada penelitian ini, pembentukan gel terjadi pada $\mathrm{pH} 7$ karena pada kondisi mendekati netral gugus fungsi silioksi ( $\mathrm{Si}$ O) dan silanol ( $\mathrm{Si}-\mathrm{OH})$ terdeprotonasi seimbang dalam jumlah yang relatif sama [15].

Selanjutnya endapan silika yang diperoleh di cuci dengan akua DM panas secara berulang dengan tujuan untuk menghilangkan pengotor dan melarutkan ion-ion garam yang masih menempel pada silika. Kadar air yang mempengaruhi kelembaban silika dihilangkan dengan proses pengeringan menggunakan oven pada temperatur $110^{\circ} \mathrm{C}$ selama 24 jam [8] sehingga didapatkan silika serbuk berwarna putih. Serbuk silika yang diperoleh dari hasil isolasi selanjutnya dikarakterisasi dengan menggunakan SEM-EDX untuk mengetahui persentase komposisi silika yang diperlihatkan pada Tabel 1.

Berdasarkan data yang diperoleh dari hasil analisis EDX, silika hasil isolasi dari rumput gajah memiliki kandungan $\mathrm{SiO}_{2}$ sebesar $71,91 \%$. Pada silika hasil isolasi masih terdapat beberapa pengotor berupa oksida-oksida logam lain, seperti $\mathrm{Na}$ dan K. Pengotor yang paling banyak terkandung adalah $\mathrm{Tm}_{2} \mathrm{O}_{3}$. Kandungan senyawa tersebut yang termasuk golongan logam tanah jarang berasal dari tanah rumput tersebut berasal, yaitu tanah di sekitar UIN Sunan Gunung Djati Bandung.

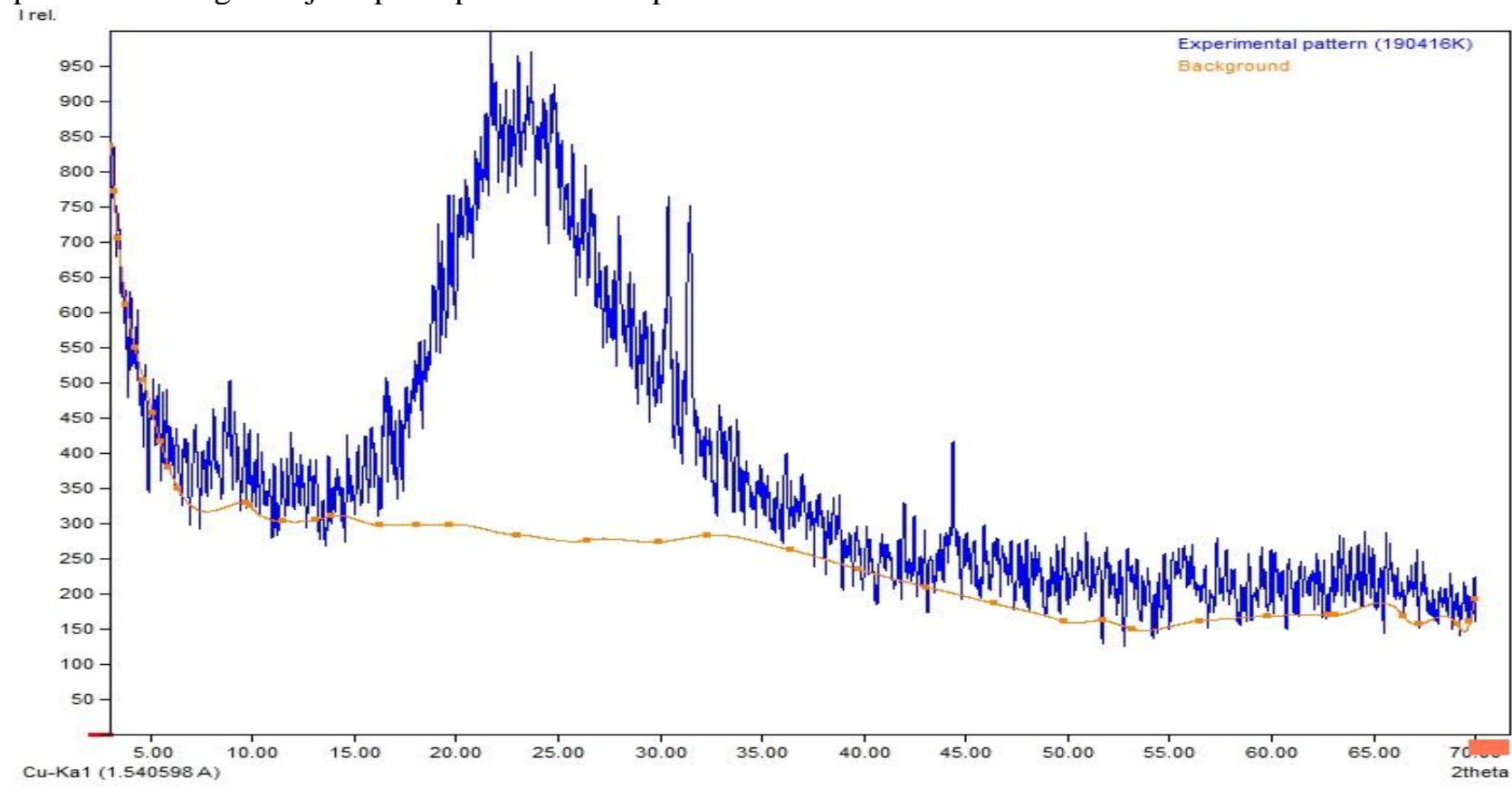

Gambar 1. Difraktogram silika rumput gajah hasil isolasi

Pola difraktogram kristalinitas silika dari isolasi daun rumput gajah dianalisis dengan menggunakan XRD. Dari pola difraktogram yang telah diperoleh, terlihat bahwa dalam silika yang terbentuk memiliki fasa campuran yaitu antara fasa kristalin dan fasa amorf. Gambar 1 menunjukkan adanya pelebaran puncak pada $20,37-24,8^{\circ}$ dengan puncak tertinggi pada $2 \theta=21,7^{\circ}$. Adanya puncak yang melebar pada difraktogram tersebut menunjukkan bahwa silika dari hasil isolasi rumput gajah memiliki fasa amorf yang terbentuk karena adanya gugus silanol ( $\mathrm{Si}-\mathrm{OH})$ pada permukaannya [16]. Akan tetapi adanya puncak pada $2 \theta=30,38^{\circ}$, $31,45^{\circ}$, dan $44,31^{\circ}$ menunjukkan bahwa terbentuk juga $\mathrm{SiO}_{2}$ yang fasa kristalin [16]. Terbentuknya fasa kristalin mengindikasikan bahwa pengotor anorganik lain dalam abu rumput gajah mengkatalisis terjadinya transformasi silika ke fasa 
kristalin yang masih menempel atau tidak larut ketika pengasaman [17]. Perbedaan antara fasa amorf dan fasa kristalin adalah adanya pelebaran puncak pada fasa amorf, sedangkan fasa kristalin menunjukkan puncak yang tajam [16]. Akan tetapi, meskipun terbentuk fasa kristalin, fasa amorf yang dihasilkan memiliki intensitas yang lebih tinggi sehingga dapat dijadikan sebagai sumber silika untuk sintesis zeolit.

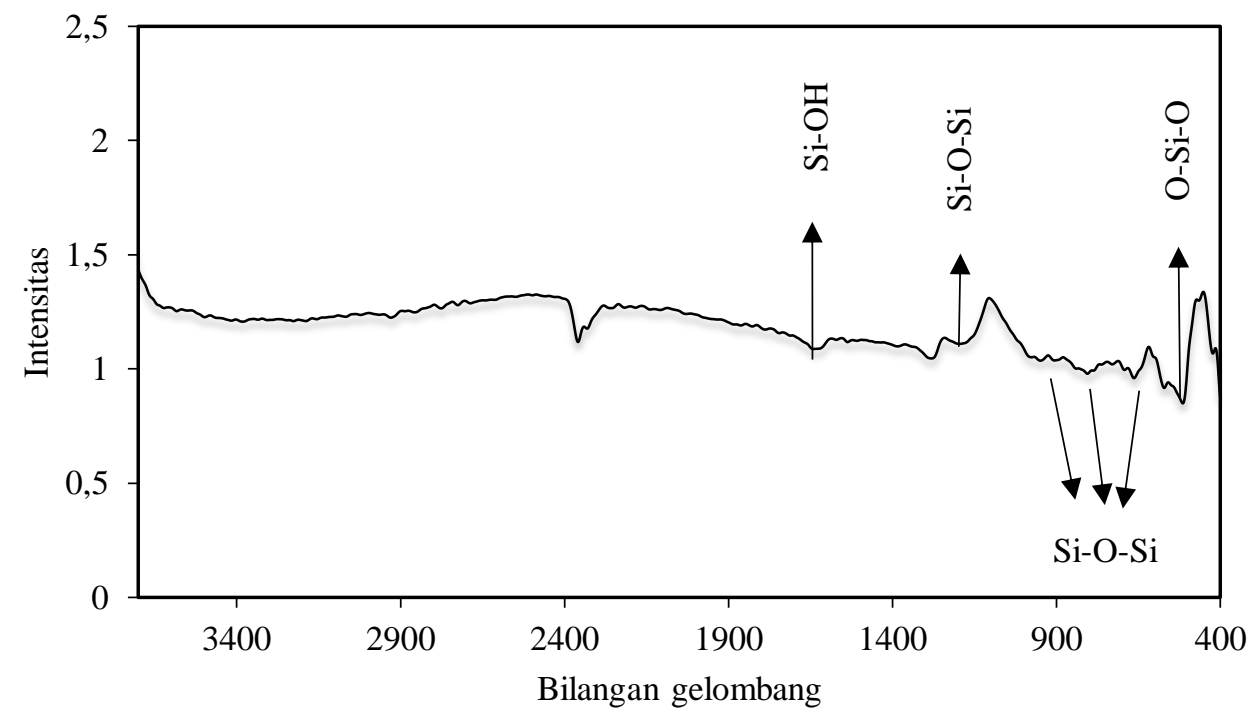

Gambar 2. Spektra FT-IR silika isolasi dari rumput gajah

Untuk mengetahui vibrasi ikatan dari silika hasil isolasi, dilakukan analisis dengan menggunakan FT-IR. Hasil analisa silika dengan FT-IR yang diperlihatkan pada Gambar 2 mengindikasikan adanya puncak pada bilangan gelombang $514 \mathrm{~cm}^{-1}, 663 \mathrm{~cm}^{-1}, 805 \mathrm{~cm}^{-1}, 984 \mathrm{~cm}^{-1}$, $1195 \mathrm{~cm}^{-1}$ dan $1641 \mathrm{~cm}^{-1}$. Pada bilangan gelombang $1641 \mathrm{~cm}^{-1}$ menunjukkan adanya vibrasi molekul $\mathrm{H}_{2} \mathrm{O}$ atau $\mathrm{Si}-\mathrm{OH}$ yang merupakan gugus yang reaktif dipermukaan silika amorf [8]. Gugus silanol merupakan gugus reaktif yang berada dipermukaan silika amorf. Selain mengindikasikan adanya gugus silanol, pada bilangan gelombang tersebut juga menindikasikan masih terdapatnya kandungan air dalam silika hasil isolasi. Bilangan gelombang 984 $\mathrm{cm}^{-1}$ menunjukkan adanya vibrasi ikatan $\mathrm{Si}-\mathrm{O}-\mathrm{Si}$ [18].

Tabel 2. Daftar bilangan gelombang silika

\begin{tabular}{|c|c|c|c|}
\hline \multicolumn{2}{|c|}{$\begin{array}{c}\text { Bilangan Gelombang } \\
\left(\mathrm{cm}^{-1}\right)\end{array}$} & \multirow[t]{2}{*}{ Interpretasi } & \multirow[t]{2}{*}{ Sumber } \\
\hline Rentang & Sampel & & \\
\hline $1650-1645$ & $\begin{array}{l}1641 \\
1195\end{array}$ & $\begin{array}{l}\text { Vibrasi tekuk } \\
\text { asimetri Si-OH } \\
\text { Vibrasi ulur } \\
\text { asimetri Si-O-Si }\end{array}$ & [8] \\
\hline $1100-700$ & 948 & $\begin{array}{l}\text { Vibrasi ulur } \mathrm{Si}- \\
\mathrm{O}-\mathrm{Si}\end{array}$ & [18] \\
\hline $820-650$ & 805 & $\begin{array}{c}\text { Vibrasi ulur } \\
\text { simetrik Si-O-Si }\end{array}$ & {$[18]$} \\
\hline $650-500$ & 663 & $\begin{array}{c}\text { Vibrasi ulur } \\
\text { simetrik Si-O-Si }\end{array}$ & [18] \\
\hline $500-420$ & 514 & $\begin{array}{l}\text { Vibrasi tekuk O- } \\
\text { Si-O }\end{array}$ & [8] \\
\hline
\end{tabular}

Analisis tambahan yang digunakan untuk mengetahui komposisi dari serbuk silika rumput gajah dengan menggunakan spektroskopi flouresensi sinar-X (XRF). Analisis ini dilakukan untuk mengonfirmasi keberadaan $\mathrm{Tm}_{2} \mathrm{O}_{3}$ yang terdapat dalam silika pada hasil analisis menggunakan EDX. Berdasarkan data yang di peroleh dari hasil analisis XRF, tidak ditemukan adanya unsur $\mathrm{Tm}$ atau oksida $\mathrm{Tm}_{2} \mathrm{O}_{3}$ baik dengan metode alloy maupun soil. Dengan demikian, belum dapat mengkonfirmasi keberadaan Tm sepenuhnya. Persentase oksida Si belum dapat diketahui sepenuhnya, akan tetapi dengan metode soil dapat mengkonfirmasi bahwa kandungan $\mathrm{Si}$ sangat besar yang diperlihatkan pada Tabel 3 .

Tabel 3. Komposisi analisis silika rumput gajah menggunakan XRF

\begin{tabular}{|c|c|c|}
\hline & Metode Soil & Metode Alloy \\
\hline $\mathrm{K}$ & $5.800 \pm 1000 \mathrm{ppm}$ & $\mathrm{Si} \quad 100,00 \pm 0,00 \%$ \\
\hline $\mathrm{Cl}$ & $4.000 \pm 3000 \mathrm{ppm}$ & \\
\hline $\mathrm{Ni}$ & $42 \pm 8 \mathrm{ppm}$ & \\
\hline $\mathrm{Fe}$ & $35 \pm 8 \mathrm{ppm}$ & \\
\hline $\mathrm{Rb}$ & $26 \pm 14 \mathrm{ppm}$ & \\
\hline $\mathrm{Cd}$ & $22 \pm 19 \mathrm{ppm}$ & \\
\hline $\mathrm{Ag}$ & $21 \pm 17 \mathrm{ppm}$ & \\
\hline $\mathrm{Zn}$ & $21 \pm 3 \mathrm{ppm}$ & \\
\hline $\mathrm{Sr}$ & $5 \pm 4 \mathrm{ppm}$ & \\
\hline $\mathrm{Zr}$ & $2 \pm 5 \mathrm{ppm}$ & \\
\hline $\mathrm{Cu}$ & $2 \pm 5 \mathrm{ppm}$ & \\
\hline $\mathrm{Br}$ & $1 \pm 3 \mathrm{ppm}$ & \\
\hline L.E. & $990.400 \pm 1400 \mathrm{ppm}$ & \\
\hline
\end{tabular}


Keterangan: LE = Light Element yang biasanya dikategorikan unsur dengan no atom $(Z)$ kurang dari 18 (argon) serta biasanya dikategorikan pada grup $\mathrm{Mg}, \mathrm{Al}$, $\mathrm{P}, \mathrm{S}, \mathrm{Si}$ dan $\mathrm{Cl}$.

Metode analisis paduan (alloy), unsur yang terdeteksi pada rentang $\mathrm{Mg}(\mathrm{Z}=12)$ sampai $\mathrm{S}$ $(Z=16)$ sarta pada $\mathrm{Ti}(\mathrm{Z}=22)$ sampai $(\mathrm{Pu})$. selain unsur tersebut, maka akan dideteksi sebagai LE ataupun jika kandungannnya kurang dari limit deteksi.

\section{Karakterisasi Zeolit T}

Pada penelitian ini telah dilakukan sintesis zeolit dengan sumber silika ynag diperoleh dari silika alam yang diisolasi dari rumput gajah. Pada umumnya, sumber silika yang biasa digunakan untuk sintesis zeolit menggunakan TEOS (Tetra Ethyl Ortho Silicate), LUDOX atau $\mathrm{Na}_{2} \mathrm{SiO}_{3}$. Namun, ketiga sumber silika tersebut memiliki kekurangan, yaitu harganya yang relatif mahal, sulit di dapat serta bahannya yang tidak ramah lingkungan [7].

Sintesis ini melibatkan pencampuran silika dan alumina dalam larutan alkali hidroksida dan air sebagai komponen dalam sintesis zeolit. Sumber silika dari rumput gajah digunakan karena mengandung silika yang tinggi, juga kelimpahannya sebagai rumput liar yang banyak sehingga dapat diperoleh dengan mudah.

Dalam proses sintesis ini menggunakan proses hidrotermal dan templat organik. Rasio mol yang digunakan untuk dintesis zeolit $\mathrm{T}$ yaitu $1 \mathrm{SiO}_{2}$ : $0,025 \mathrm{Al}: 0,15 \mathrm{NaOH}: 0,15 \mathrm{KOH}: 0,06 \mathrm{TMAOH}$ : $15 \mathrm{H}_{2} \mathrm{O}$ dengan waktu diinkubasi di dalam oven menggunakan autoklaf sebagai wadah selama 4 hari, 2 hari pada temperatur $60^{\circ} \mathrm{C}$ dan 2 hari berikutnya pada temperatur $120^{\circ} \mathrm{C}$. [10].

Pada sintesis zeolit $\mathrm{T}$ hal yang pertama dilakukan adalah melarutkan logam aluminium dengan larutan $\mathrm{NaOH}$. Proses pelarutan logam aluminium akan terbentuk aluminat (ion tetrahidroksoalumina), dengan reaksi sebagai berikut :

$$
\mathrm{Al}+4 \mathrm{OH}^{-} \rightarrow\left[\mathrm{Al}(\mathrm{OH})_{4}\right]^{-}
$$

Setelah aluminium terlarut, semua prekursor dicampurkan ke dalam satu wadah kemudian dilakukan pengadukan selama 20 jam agar campuran menjadi homogen dan membentuk gel prekursor. Penambahan larutan alkali karena golongan alkali kuat untuk mempercepat proses pelarutan campuran reaksi. Ion hidroksida yang terdapat dari kedua senyawa tersebut berperan sebagai derajat polimerisasi dalam larutan dan termasuk pengompleks yang baik bagi alumina dan silikat. Dalam bentuk konjugasinya dengan pelarut air, ion hidroksida bertindak sebagai pengangkut silikat dan aluminat antara fase amorf dan fase kristalin zeolit. Selain itu, penambahan $\mathrm{KOH}$ dan $\mathrm{NaOH}$ berperan sebagai penyeimbang $\mathrm{pH}$ basa juga berfungsi sebagai pembentuk kation penyeimbang kerangka. Parameter lain yang mempengaruhi terbentuknya fasa dari sintesis zeolit adalah rasio molar Si/Al, konsentrasi larutan alkali hidroksida, kadar air, temperatur dan waktu [19].

Sintesis ini juga menggunakan suatu templat organik TMAOH. Penambahan templat organik dibutukan untuk menstabilkan struktur pori tertentu yang membuat banyak jenis zeolit ditemukan, salah satunya zeolit T. Templat tersebut akan membentuk cetakan dan dikelilingi oleh ion-ion pembentuk kerangka zeolit yang disebabkan oleh interaksi Van der Waals antara ion $\left[\mathrm{SiO}_{4}\right]^{-3}$ atau $\left[\mathrm{AlO}_{4}\right]^{-5}$. Adanya kation $\mathrm{TMA}^{+}$dalam campuran akan berekasi cepat dengan anionik yaitu ion silikat. Setelah kristal zeolit terbentuk, tamplat dihilangkan dengan cara kalsinasi, karena apabila templat tidak dihilangkan akan menggangu stabilitas zeolit yang biasanya stabil dalam temperatur tinggi [20].

Setiap jenis zeolit membutuhkan waktu inkubasi yang berbeda. Pada saat dilakukannya inkubasi maka fase amorf sekunder terbentuk, yaitu fase dimana kerangka zeolit mulai tersusun. Proses inkubasi ini merupakan proses dimulainya pengintian (nukleasi) dan pertumbuhan kristal. Nukleasi merupakan suatu proses kompleks yang mengubah struktur yang awalnya berfasa amorf menjadi suatu kerangka kristalin. Setelah proses nukleasi, kemudian terjadi pertumbuhan kristal, pertumbuhan kristal ini merupakan suatu proses dimana atom atau molekul bergabung ke dalam permukaan kristal yang menyebabkan peningkatan ukuran.

Pada zeolit T inkubasi yang dilakukan cukup lama, yaitu sampai dengan 8 hari [9], akan tetapi tersebut tentunya kurang efisien karena membutuhkan banyak energi. Yin et al. telah berhasil mensintesis zeolit $\mathrm{T}$ dengan waktu yang lebih cepat yakni dalam waktu 4 hari dengan variasi waktu inkubasi [10]. Oleh karena itu, metode sintesis zeolit $\mathrm{T}$ pada ini menggunakan metode hidrotermal dengan diinkubasi di dalam oven selama 4 hari, 2 hari petama pada temperatur $60^{\circ} \mathrm{C}$ sedangkan 2 hari berikutnya pada temperatur 120 ${ }^{\circ} \mathrm{C}$ yang merujuk pada penelitian Yin et al.. Dalam metode hidrotermal, temperatur dapat mengubah fasa zeolit sebelum proses kristalisasi. Ketika temperatur campuran meningkat, tingkat kristalisasipun meningkat dan mendukung pembentukan fasa lainnya. Komponen $\mathrm{Al}$ dan $\mathrm{Si}$ dalam fasa cair berperan sebagai pengendali utama pembentukan zeolit. Dengan meningkatnya 
temperatur, kelarutan dari aluminat dan komponen silikat akan terjadi peningkatan tetapi tidak pada tingkat yang sama [19].

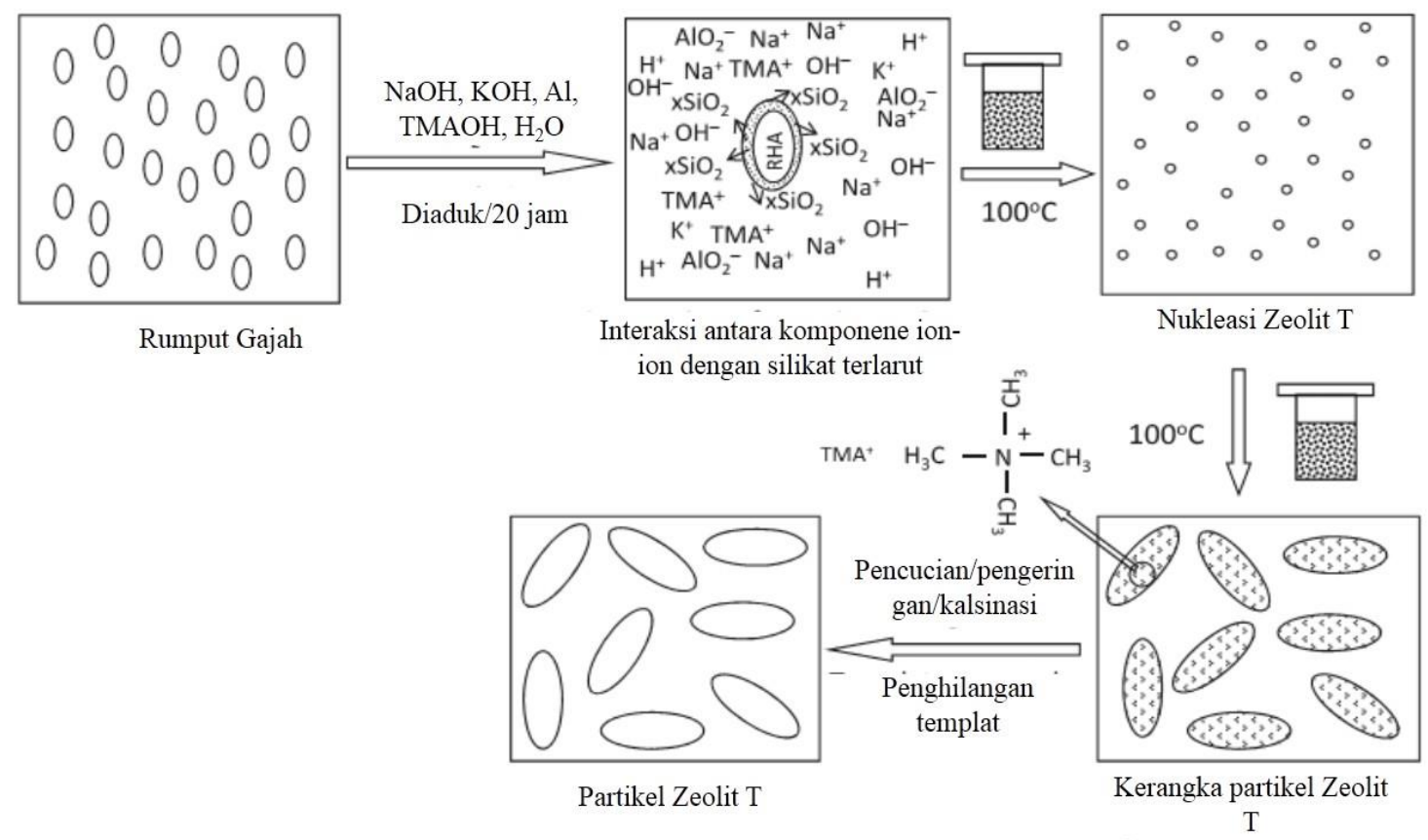

Gambar 3. Skema sintesis serbuk T zeolit menggunakan abu daun rumput gajah sebagai sumber silika [9]

Zeolit $\mathrm{T}$ merupakan tipe zeolit dengan kandungan $\mathrm{Si}$ sedang karena mempunyai rasio Si/Al 3, atau berada diantara 2 sampai 5. Zeolit erionit mempunyai sintem saluran/struktur poros 3 dimensi yang di bangun dari unit pembangun sekunder, sehingga molekul yang berdifusi dapat bergerak ke semua arah atau sisi kristal. Unit bangun sekunder dari zeolit $\mathrm{T}$ adalah cincin segi empat dan segi enam, sehingga akan menyebabkan ketidaksimetrisan ukuran. Selain itu, ketidaksimetrisan tersebut karena pada susunan lapisan kedua mengalami pergeseran bersama di dua sisi [21].

\section{Karakterisasi dengan Difraksi Sinar- $X$}

Metode analisis dengan XRD meruapakan suatu metode analisis kualitataif yang memberikan informasi mengenai struktur dan tingkat kristalinitas suatu mineral dengan melihat difraktogramnya. Analisis dilakukan pada kondisi operasi radiasi $\mathrm{Cu}-\mathrm{K} \alpha$ dengan sudut $2 \theta$ sebesar 5$60^{\circ}$. Analisis dilakukan dengan membandingkan puncak-puncak difraksi mineral tertentu dengan Joint Commitee Powder on Diffraction Standarts (JCPDS).

Material dengan kristalinitas yang baik memiliki intensitas ketajaman puncak yang tinggi serta pemisahan puncak yang baik. Berdasarkan penelitian yang telah dilaporkan oleh peneliti sebelumnya [3], penambahan TMAOH berpengaruh terhadap intensitas puncak zeolit $\mathrm{T}$ yang dihasilkan. Yin et al. berhasil melakukan sintesis dengan intensitas puncak yang optimal, yakni sesuai dengan karakteristik zeolit $\mathrm{T}(2 \theta=$ $7,69)$. Penelitian tersebut melaporkan juga bahwa kristal zeolit $\mathrm{T}$ berhasil di bentuk setelah diinkubasi 48 jam.

Hasil pengukuran pada Gambar 4 menunjukkan adanya puncak khas pada $2 \theta=7.72^{\circ}$, $13.44^{\circ}, 20.49^{\circ}, 23.70^{\circ}, 24.85^{\circ}, 28.32^{\circ}, 31,44^{\circ}$. Pada zeolit $\mathrm{T}$ hasil sintesis nampak puncak-puncak yang melebar apabila dibandingkan dengan difraktogram standar zeolit T. Pelebaran puncak ini biasanya disebabkan oleh ukuran kristal yang dianalisis, semakin kecil ukuran kristalitnya maka puncak yang dihasilkan pada difraktogram akan semakin melebar. Selain terjadi pelebaran puncak, pada zeolit $\mathrm{T}$ hasil sintesis ini mengalami penurunan intensitas yang dipengaruhi oleh regangan kisi pada kristal. Ketika terjadi penurunan intensitas, hal tersebut menunjukkan kristalinitas dari zeolit $\mathrm{T}$ menurun dibandingkan dengan zeolit $\mathrm{T}$ standar. Walaupun zeolit yang dihasilkan memiliki pelebaran puncak dan mengalami penurunan intensitas, zeolit yang terbentuk memiliki kesesuaian dengan zeolit standar. Hal tersebut menunjukan bahwa zeolit $\mathrm{T}$ dapat di sintesis dengan menggunakan daun rumput gajah sebagai sumber silika alternatif. 


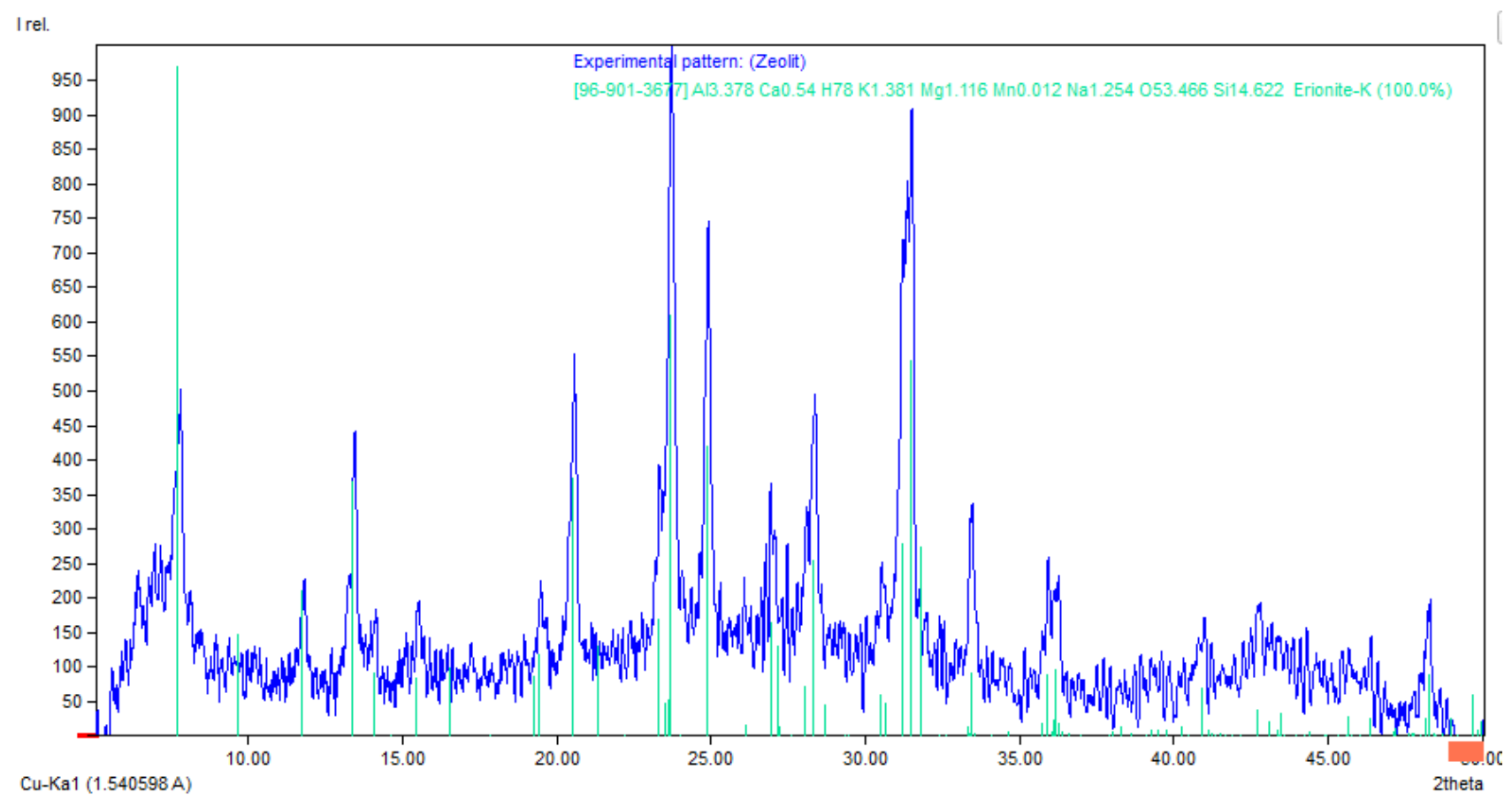

Gambar 4. Difraktogram Zeolit T hasil sintesis

Analisis kuantitatif dilakukan untuk mengetahui ukuran kristal yang dihasilkan dari sintesis zeolit. Dari difraktogram tersebut dapat diketahui bahwa ukuran kristal yang terbentuk sebesar 28,44 nm. Berdasarkan persamaan Bragg dapat diketahui jarak antarpartikel zeolit $\mathrm{T}$ hasil sintesis sebeasar 3,7516 ̊. Menurut Du dan Wu jarak antarpartikel berbanding lurus dengan ukuran kristal. Ukuran kristal yang kecil menyebabkan jarak antar partikel menjadi kecil, sehingga struktur kristal yang terbentuk semakin rapat dan teratur.
Struktur kristal yang semakin rapat dan teratur menyebabkan derajat kristalinitasnya tinggi [22].

\section{Karakterisasi dengan Fourier Transform Inrfrared (FTIR)}

Karakterisasi zeolit dengan FT-IR bertujuan untuk mengidentifikasi gugus fungsi dan vibrasi ikatan yang terdapat dalam zeolit. Hasil FT-IR zeolit diperlihatkan pada Gambar 5.

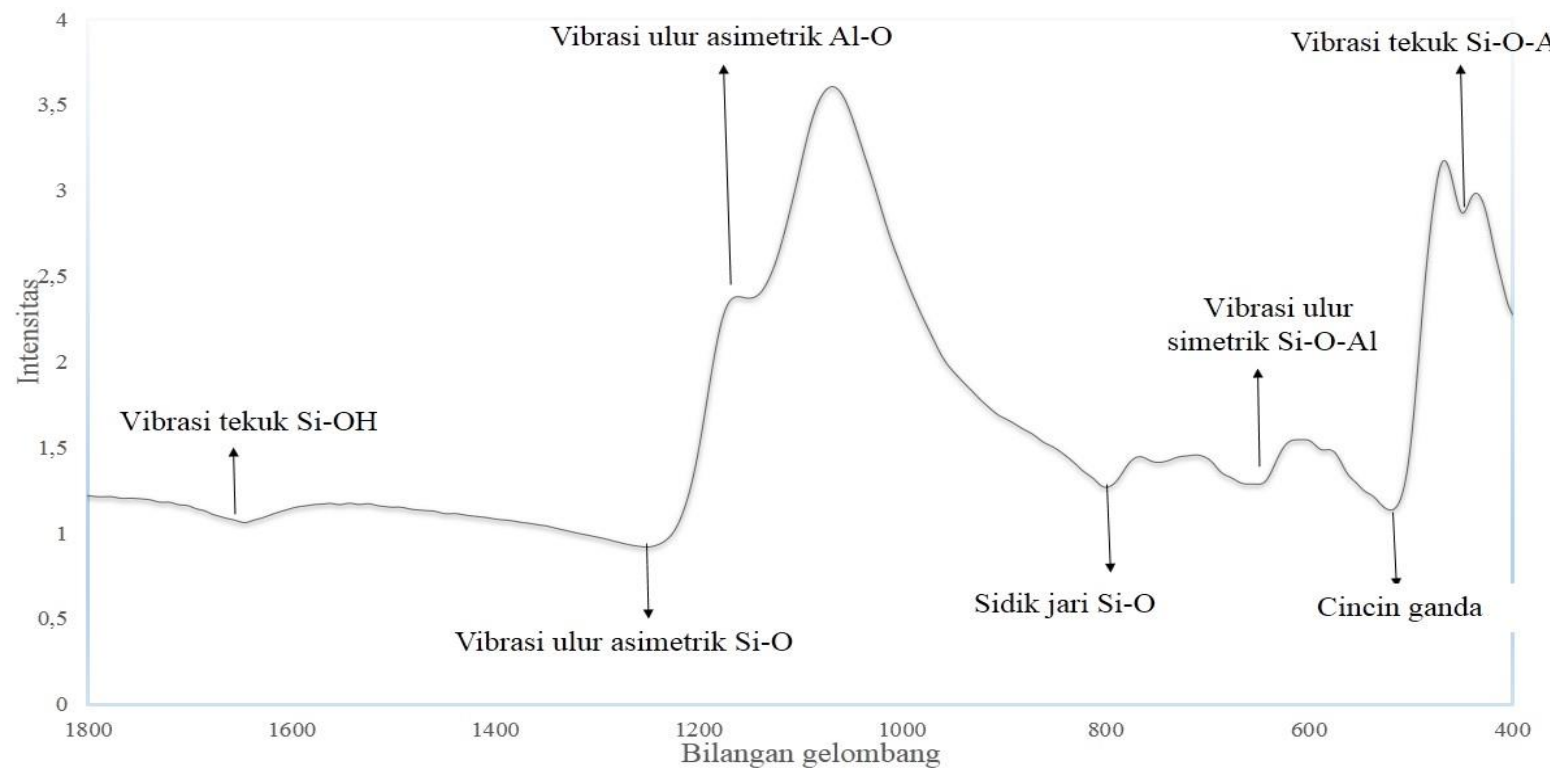

Gambar 5. Spektra FT-IR zeolit T

Daerah serapan sekitar 1100-700 $\mathrm{cm}^{-1}$ merupakan sidik jari dari zeolit yang menunjukkan adanya vibrasi Si-O [23]. Serapan pada bilangan gelombang $800 \mathrm{~cm}^{-1}$ mengindikaskan sidik jadi Si- 
O karena terletak di daerah bilangan gelombang yang lebih tinggi, sedangkan apabila yang terbentuk daerah yang lebih rendah menunjukkan sidik jari Al-O. Pada struktur zeolit terdapat jalinan internal yang muncul pada daerah serapan 1250$950 \mathrm{~cm}^{-1}$ menunjukkan adanya vibrasi ulur simetri Si-O-Al dalam kerangka aluminasilikat yang disebabkan adanya ikatan antar tetrahedral. Sedangkan untuk jalinan eksternal adanya vibrasi ulur simetri Si-O-Al pada daerah serapan $820-650$ $\mathrm{cm}^{-1}[18]$.

Tabel 4. Daftar bilangan gelombang sintesis zeolit

\begin{tabular}{|c|c|c|c|}
\hline \multicolumn{2}{|c|}{$\begin{array}{c}\text { Bilangan } \\
\text { Gelombang }\left(\mathrm{cm}^{-1}\right)\end{array}$} & \multirow[t]{2}{*}{ Interprestasi } & \multirow[t]{2}{*}{ Referensi } \\
\hline Rentang & Sampel & & \\
\hline $1650-1645$ & 1646 & $\begin{array}{l}\text { Vibrasi tekuk } \\
\text { Si-OH }\end{array}$ & \\
\hline $1250-950$ & $\begin{array}{l}1251 \\
1150\end{array}$ & $\begin{array}{l}\text { Vibrasi ulur } \\
\text { asimetrik Si-O } \\
\text { dan Al-O }\end{array}$ & \\
\hline $1100-700$ & 800 & Sidik jari Si-O & {$[23]$} \\
\hline $820-650$ & 661 & $\begin{array}{l}\text { Vibrasi ulur } \\
\text { simetrik Si-O- } \\
\mathrm{Al}\end{array}$ & \\
\hline $650-500$ & 519 & Cincin ganda & \\
\hline $500-420$ & 449 & $\begin{array}{l}\text { Vibrasi tekuk } \\
\text { Si-O-Al }\end{array}$ & {$[18]$} \\
\hline
\end{tabular}

Karakteristik penting yang harus ada pada zeolit adalah adanya cincin ganda. Cincin ganda merupakan jalinan eksternal antara zeolit yang dapat dilihat pada bilangan gelombang 650-500 $\mathrm{cm}^{-1}$. Pada zeolit $\mathrm{T}$, jalinan tersebut merupakan Dari data yang diperoleh terdapat serapan pada bilangan gelombang $519 \mathrm{~cm}^{-1}$ yang menunjukkan bahwa dalam sintesis zeolit ini terdapat adanya cincin ganda. Vibrasi tekuk dari Si-O-Al pada kerangka aluminasilikat muncul pada serapan 500$420 \mathrm{~cm}^{-1}$. Adanya vibrasi ulur dan tekuk dari Si-OAl menunjukkan bahwa telah telah terbentuknya karengaka aluminasilikat [18].

\section{Karakterisasi dengan Mikroskop Pemindai Elektron (SEM)}

Karakterisasi dengan SEM dilakukan untuk mengetahui morfologi dari kristal zeolit yang terbentuk serta memperkirakan ukuran partikelnya. Morfologi sampel diperlihatkan pada Gambar 6. Pada umumnya ukuran partikel zeolit $\mathrm{T}$ berada pada rentang 100-25 nm, hal tersebut dipengaruhi oleh parameter formula sol-gel seperti rasio molar $\mathrm{SiO}_{2} / \mathrm{Al}_{2} \mathrm{O}_{3}, \mathrm{~K}_{2} \mathrm{O} / \mathrm{N}_{2} \mathrm{O}$ dan penambahan TMAOH [10].
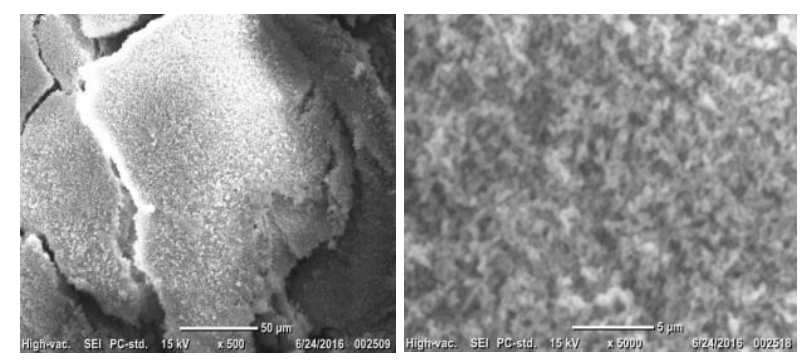

Gambar 6. Morfologi zeolit $\mathrm{T}$ pada pembesaran 500x dan 5000x

Pada Gambar 6 diperlihatkan morfologi kristal zeolit yang terbentuk dengan pembesaran skala 500 dan 5000 kali. gambar tersebut memperlihatkan hasil yang kurang baik karena bentuk/morfolofi dari zeolit yang terbentuk tidak terlihat jelas sehingga sulit untuk menentukan jenis bentuk zeolit tersebut. Hal tersebut karena alat yang digunakan kurang sesui dengan kristal zeolit yang dihasilkan.

\section{SIMPULAN}

Dari hasil penelitian ini dapat ditarik simpulan bahwa Silika dapat diisolasi dari rumput gajah yang dikonfirmasi menggunakan XRD berfasa amorf sehingga dapat dijadikan sebagai sumber silika untuk sintesis zeolit T. Berdasarkan hasil analisis EDX, di dalam rumput gajah mengandung silika sebesar $71,91 \%$. Zeolit $\mathrm{T}$ berhasil disintesis menggunakan silika rumput gajah dengan waktu sintesis selama 4 hari menggunakan variasi temperatur yaitu 2 hari pertama pada temperatur $60^{\circ} \mathrm{C}$ dan 2 hari selanjutnya pada temperatur $120^{\circ} \mathrm{C}$

\section{UCAPAN TERIMA KASIH}

Penulis mengucapkan terima kasih kepada Laboratorium Instrumen Kimia FST UIN SGD Bandung atas diskusi interpretasi Fourier Transform Infra Red (FTIR); Laboratorium Fisika FST UIN SGD Bandung atas diskusi SEM-EDX; Laboratorium Pusat Survei Geologi (PSG) dan Pusat Penelitian Bahan Tambang Teknik Mineral Batubara (PUSLITBANG TekMIRA) atas diskusi metode $X$-Ray Diffraction (XRD); Lembaga Ilmu Pengetahuan Indonesia (LIPI) Serpong atas analisis meyode $X$-Ray fluorescence (XRF).

\section{REFERENSI}

[1] Masato Tsujiguchi et al., "Synthesis and Characterization of Zeolite from Glass by Hydrothermal Processing," Materials Science Forum, pp. 91-94, 2013. 
[2] H. J. Zhan, X. H. Lu, X. T. Mar, and Q. H. Xia, , T. W. Wong, Ed. New York, United States of America: Nova Science Publisher, 2009, ch. 20.

[3] Xiaoyan Yin et al., "Hydrothermal synthesis of hierarchical zeolite $\mathrm{T}$ aggregates using tetramethylammonium hydroxide as single template," Microporous and Mesoporous Materials, no. 201, pp. 247-257, September 2015.

[4] R. Zhou, S. Zhong, X. Lin, and N. Xu, "Synthesis of Zeolite $\mathrm{T}$ by microwave and conditional heating," Micropor, Mesopor, Mater, vol. 124, pp. 164-172, 2009.

[5] S. M. Mirfendereski, T. Mazaheri, M. Sarzadeh, and T. Mohammadi, "CO2 dan $\mathrm{CH} 4$ permeation through T-type Zeolite Membrane : Effect of synthesis parameters and feed pressure," vol. 61, pp. 317-323, 2008.

[6] Korosh Shafiei, Mansour Kazemi Moghaddam, Shahramghanbari Pakdehi, and Toraj Mohammadi, "Hydrothermal Synthesis of Nanosized Zeolite T Crystals," Particulate Science and Technology, 2013.

[7] R. Balgis, A. Purwanto, S. Winardi, H. Setyawan, and S Affandi, A Facile Method for Production pf High-Purity Silica Xerogels from Bagasse Ash.: Advanced Technology, 2009.

[8] V. Vaibhav, U. Vijayalakshmi, and S. M. Roopan, "Agricultural waste as a source for the production of silica nanoparticles," Spectrochimica Acta Part A: Molecular and Biomolecular Spectroscopy, 2014.

[9] S. Bohra, K. P. Dey, and D. Kundu, "Synthesis of Zeolite T Powders by Direct Dissolution of Rice Husk Ash," An Agro-waste Material, 2013.

[10] X. Yin, N. Chu, X. Chu, Z. Li, and H. Guo, "Studies on the Formation of Hierarchical Zeolite $\mathrm{T}$ Aggregates with Well-defined Morphology in Different Template Systems," Solid State Sciences, no. 51, pp. 30-39, 2016.

[11] World Health Organization, "Crystalline silica, quartz.," National Institute of Occupational Safety and Health dan World Health Organization, Geneva, (Concise international chemical assessment document ; 24) 924 153023 5/ 1020-6167, 2000.

[12] J. Umeda, H. Imai, and K. Kondoh, "Polysaccharide Hydrolysis and Metallic Impurities Removal Behavior of Rice Husk in
Citrit Acid Leaching Treatment," Transactions of JWRI, vol. 38, pp. 13-18, 2009.

[13] Taro Saito, Buku Teks Kimia anorganik. Tokyo: Permission of Iwanami Shoten, 2004.

[14] Luana Erviana, "Isolasi Silika Dari Tongkol Jagung," Surabaya, 2013.

[15] V. A. Chakraverty and Fabiani, "Pengaruh Agen Pengarah struktur Zeolit pada Sintesis ZSM-5 dengan Prekursor Silika Alam," 2014.

[16] P. Velmurugan et al., "Extraction, characterization, and catalytic potential of amorphous silica from corn cobs by sol-gel method," Journal of Industrial and Engineering Chemistry, 2015.

[17] "Crystalline silica, quartz," World Health Organization, Geneva, WHO Library Cataloguing ISBN 924 153023 5/ISSN 1020$6167,2000$.

[18] Mozgawa, Krol, and Barczyk, "FT-IR Studies of Zeolite from Different Structural Groups," Chemik, pp. 667-674, 2011.

[19] P. Khummongko and R Anuwattana, "Synthesis of Zeolites from Industrial Wastes," in Handbook of Zeolites, T. W. Wong, Ed. Bangkok, Thailand: Nova Science Publishers, 2009, ch. 17, pp. 469-498.

[20] K. Byrappa and Yoshimura, "Hydrothermal Synthesis and Growth of Zeolites," in Handbook Of Hydrothermal Technology, Masahiro, Ed. Yokohama, Jepang: University ofMysore Manasagangotri Mysore, India \& Tokyo Institute of Technology, 2001, pp. 315414.

[21] (2016, Juni) IZA Structure. [Online]. http://www.izastructure.org/databases/ModelBuilding/ERI.pdf

[22] X. Du and E. Wu, "Porosity of Microporous Zeolit A, X dan ZSM-5 Studied by Small Angel X-Ray Scattering and Nitrogen Adsorpsion ," Journal of Physics and Chemistry of Solids, vol. 68, pp. 1962-1699, 2007.

[23] M. M. Dubinin, V. Ya. Nikolina, L. I. Piguzova, and T. N. Shishakova, "STRUCTURE OF SYNTHETIC ERIONITE (ZEOLITE T), , pp. 1116-1118, Juni 1965. 